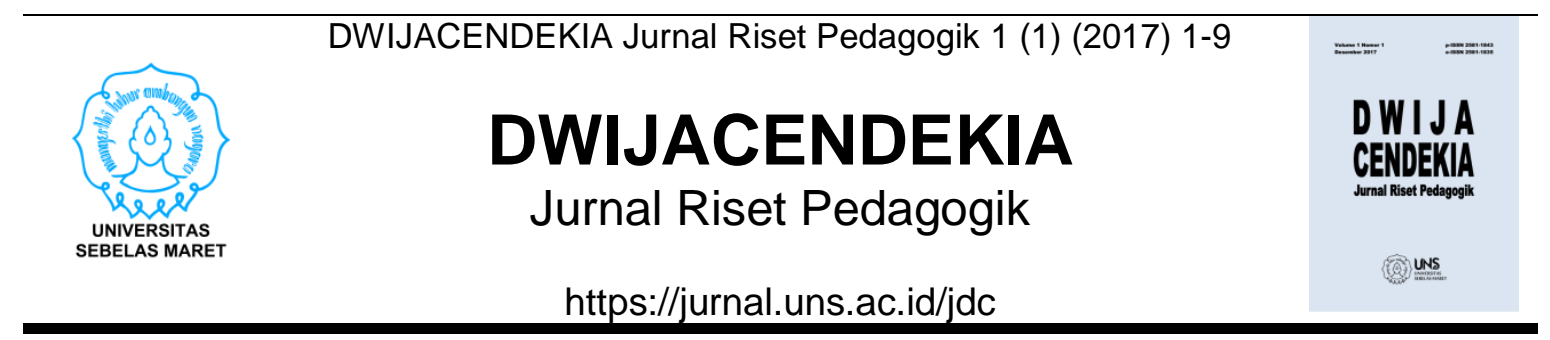

\title{
PENINGKATAN KETERAMPILAN MENULIS DESKRIPSI MELALUI PENGGUNAAN MEDIA GAMBAR BERSERI DI KELAS IV SD NEGERI 01 DAYA ASRI KABUPATEN TULANG BAWANG BARAT
}

\section{Arum Sulastri}

\section{STKIP PGRI Metro}

\section{Sejarah Artikel}

Diterima 3 Juli 2017

Disetujui 10 Juli 2017

Diterbitkan 1 Agustus 2017

\section{Kata Kunci}

keterampilan menulis deskripsi, media gambar berseri

\begin{abstract}
Abstrak
Tujuan penelitian ini untuk meningkatkan keterampilan pembelajaran menulis deskripsi bahasa Indonesia siswa kelas IV. Subject penelitian adalah siswa kelas IV yang berjumlah 27 siswa. Metode penelitian yang digunakan yaitu dengan penelitian tindakan kelas meliputi perencanaan, pelaksanaan, observasi. dan refleksi. Data kegiatan tersebut dikumpulkan melalui lembar observasi, hasil tes pada setiap akhir siklus. Analisis data menggunakan kualitatif dan kuantitatif. Hasil penelitian siklus I rata-rata aktivitas siswa (51\%), siklus II $(70 \%)$ dan siklus III (81\%). Peningkatan rata-rata aktivitas siklus I ke siklus II (19\%) dan siklus II ke siklus III (11\%). Ratarata hasil belajar siswa siklus I (65\%), siklus II (69\%) dan siklus III (73\%). Peningkatan rata-rata hasil belajar siswa siklus I ke siklus II (4\%) dan siklus II ke siklus III (4\%). Pada siklus I kinerja guru belum maksimal dalam penguasaan kelas, dengan rata-rata aktivitas (46,5\%). Pada siklus II kinerja guru meningkat yaitu dapat membimbing dan menguasai kelas $(55 \%)$ dan siklus III (61\%). Kinerja guru mengalami peningkatan dari siklus I ke siklus II (8,5\%) dan siklus II ke siklus III (6\%). Hasil penelitian menunjukkan bahwa penggunaan media gambar berseri dapat meningkatkan keterampilan menulis deskripsi siswa kelas IV. Bedasarkan hasil temuan, disarankan pada guru bidang studi bahasa Indonesia hendaknya menerapkan media gambar berseri dalam pembelajaran.
\end{abstract}

\section{Cara Mengutip}

Sulastri, A. (2017). Peningkatan Keterampilan Menulis Deskripsi Melalui Penggunaan Media Gambar Berseri di Kelas IV SD Negeri 01 Daya Asri Kabupaten Tulang Bawang Barat. DWIJACENDEKIA Jurnal Riset Pedagogik, 1(1), 1-9. 


\section{PENDAHULUAN}

Pendidikan merupakan hal yang sangat penting bagi peradaban manusia dan peradaban bangsa, oleh karena itu pendidikan perlu direkontruksi secara baik. Menurut Rahardja dan Sulo (dalam Mikarsa, 2007: 1.18) pendidikan adalah usaha atau kegiatan yang dilaksanakan dengan sengaja, teratur, dan terencana untuk membina kepribadian dan pengembangan kemampuan manusia baik jasmani maupun rohani, sehingga pendidikan mempunyai peran yang sangat menetukan, bagi perkembangan individu maupun suatu bangsa.

Untuk memprogramkan pendidikan yang berkualitas, maka perlu adanya pedoman-pedoman yang ditaati salah satunya yaitu kurikulum yang baik. Menurut Hernawan dkk, (2008: 1.5) kurikulum adalah suatu rencana tertulis yang disusun guna memperlancar proses belajar mengajar untuk pencapaian tujuan pendidikan. Kurikulum yang digunakan saat ini adalah Kurikulum Tingkat Satuan Pendidikan (KTSP) yang merupakan penyempurnaan dari kurikulum 2004 yaitu Kurikulum Berbasis Kompetensi (KBK).

Salah satu tujuan pembelajaran bahasa menurut KTSP (2006: 4) menyebutkan pembelajaran bahasa memiliki peran sentral dalam perkembangan intelektual, sosial, dan emosional peserta didik dan merupakan penunjang keberhasilan dalam mempelajari semua bidang studi. Pembelajaran bahasa diharapkan membantu peserta didik mengenal dirinya, budayanya, dan budaya orang lain, mengemukakan gagasan dan perasaan, berpartisipasi dalam masyarakat yang menggunakan bahasa tersebut, dan menemukan serta menggunakan kemampuan yang ada dalam dirinya.

Mata Pelajaran bahasa Indonesia sekolah dasar (SD) merupakan mata pelajaran yang penting atau strategis terhadap pembelajaran di SD karena melalui bahasa seorang guru dapat menyalurkan ilmu pengetahuan, teknologi, seni, dan informasi kepada siswa. Dalam pembelajaran bahasa Indonesia di SD terdapat empat aspek keterampilan yang dikembangkan yaitu: menyimak, berbicara, membaca, dan menulis ditambah dua aspek penunjang yakni kebahasaan dan apresiasi bahasa dan sastra Indonesia SD.

Depdiknas (2002: 2.6) menyebutkan tujuan pembelajaran bahasa Indonesia di SD adalah (1) siswa menghargai dan membanggakan bahasa Indonesia sebagai bahasa persatuan dan bahasa Negara; (2) siswa memahami bahasa Indonesia dari segi bentuk, makna dan fungsi serta menggunakanya dengan tepat dan kreatif dalam bermacam-macam tujuan; (3) siswa memiliki kemampuan menggunakan bahasa Indonesia untuk meningkatkan kemampuan intelektual, kematangan emosional dan sosial; (4) siswa memiliki kedisiplinan dalam berpikir dan berbahasa; (5) siswa mampu menikmati dan memanfaatkan karya sastra untuk mengembangkan kepribadian, wawasan kehidupan, meningkatkan kemampuan berbahasa; (6) siswa menghargai dan membanggakansastra Indonesia sebagai khasanah budaya dan intelektual. 
Menulis merupakan salah satu aspek keterampilan berbahasa yang harus dikuasai dengan baik oleh siswa. Melalui menulis seseorang dapat mengungkapkan perasaan, ide, gagasan. Menulis merupakan media untuk berkomunikasi seseorang kepada orang lain.

Menurut Warsito (2009: 2) dalam penelitian karya ilmiahnya yang berjudul "Penggunaan Media Gambar Berseri untuk Meningkatkan Keterampilan Menulis Karangan Narasi" mengemukakan bahwa banyak guru SD mengalami kesulitan untuk membiasakan anak belajar menulis. Penyebabnya adalah kesalahan dalam hal pengajaran yang terlalu kaku sehingga menimbulkan kesan bahwa menulis itu sulit. Selain itu guru SD banyak pula yang belum memahami pentingnya keterampilan menulis. Banyak dari mereka yang tidak bisa menyuguhkan materi pelajaran dengan cara yang tepat dan menarik. Oleh karena itu, wajar jika murid pun akhirnya tidak mampu dan tidak menyukai pelajaran menulis (mengarang) sehingga menjadi malas untuk menulis. Indikatornya yaitu kemampuan keterampilan menulis diskripsi siswa SD belum baik. Siswa SD dalam menulis kurang dapat berimajinasi dan masih sedikit tulisannya yang dinilai baik, yaitu gagasannya diungkapkan secara jelas dengan urutan yang logis. Pada umumnya anak kurang dapat mengelola gagasan secara sistematis.

Proses pembelajaran merupakan kegiatan yang di dalamnya terdapat berbagai komponen pengajaran, yang terdiri atas: guru, tujuan pembelajaran, materi pembelajaran, media, sistem pengajaran, sumber pelajaran, manajemen intraksi, evaluasi dan siswa. Guna mencapai hasil belajar yang optimal, semua komponen di dalam proses belajar mengajar tersebut tidak boleh diabaikan. Salah satu komponen tersebut adalah penggunaan media dalam pembelajaran (Winataputra dkk, 2008: 1.21). Propinsi Lampung mempunyai beberapa Kabupaten yang salah satunya yaitu Kabupaten Tulang Bawang Barat yang merupakan daerah otonomi baru.

Berdasarkan hasil observasi yang dilakukan peneliti. Dalam pembelajaran bahasa Indonesia khususnya aspek menulis siswa yang telah mencapai Kriteria Ketuntasan Minimal (KKM) adalah $40 \%$ dan $60 \%$ siswa belum mencapai $\mathrm{KKM}$, sedangkan KKM yang ditentukan mendapatkan nilai 63. Rendahnya hasil belajar siswa tersebut diperkirakan akibat kurangnya penggunaan media pembelajaran sehingga kegiatan pembelajaran kurang optimal bagi siswa. Proses kegiatan pembelajaran ini, masih menggunakan metode konvensional yang ditandai dengan ceramah diiringi dengan penjelasan, serta pembagian tugas dan latihan.

Berdasarkan bahasan di atas dapat disimpulkan identifikasi masalah sebagai berikut:

1. Proses pembelajaran bahasa Indonesia selama ini kurang diminati siswa,

2. Guru belum menggunakan media pembelajaran yang inovatif, kreatif dan menyenangkan secara maksimal.

3. Siswa kurang tertarik pada pelajaran bahasa Indonesia khususnya menulis deskripsi, 
4. Hasil belajar siswa belum mencapai KKM yang telah ditetapkan.

Berdasarkan identifikasi masalah di atas, penulis merumuskan masalah dalam penelitian yaitu: "Bagaimanakah meningkatkan keterampilan menulis deskripsi dengan menggunaan media gambar berseri pada siswa kelas IV SD Negeri 01 Daya Asri Kabupaten Tulang Bawang Barat?".

Secara umum penelitian ini bertujuan Peningkatan keterampilan menulis deskripsi dengan menggunakan media gambar berseri pada siswa kelas IV SD Negeri 01 Daya Asri Kabupaten Tulang Bawang Barat.
Secara khusus penelitian ini bertujuan:

1. Mendeskripsikan perencanaan pembelajaran keterampilan menulis deskripsi dengan menggunakan media gambar berseri di kelas IV SD Negeri 01 Daya Asri Kabupaten Tulang Bawang Barat.

2. Mendeskripsikan pelaksanaan pembelajaran keterampilan menulis deskripsi dengan menggunakan media gambar berseri di kelas IV SD Negeri 01 Daya Asri Kabupaten Tulang Bawang Barat.

3. Mendeskripsikan model evaluasi pembelajaran keterampilan menulis deskripsi dengan menggunakan media gambar berseri di kelas IV SD Negeri 01 Daya Asri Kabupaten Tulang Bawang Barat.

\section{METODE PENELITIAN}

Penelitian ini menggunakan metode dan rancangan penelitian tindakan yang difokuskan pada situasi kelas, atau lazimnya dikenal dengan classroom action research (penelitian tindakan kelas).. Penelitian tindakan kelas ini adilaksanakan secara kolaboratif partisipatif antara peneliti dengan guru SD Negeri 01 Daya Asri. Subject penelitian adalah siswa kelas IV SD Negeri 01 Daya Asri, Kabupaten Tulang Bawang Barat Tahun 2009/2010 yang berjumlah 27 siswa. Penelitian ini menggunakan model penelitian Hopkins yang dikutip Arikunto (2006). Siklus ini tidak hanya berlangsung satu kali tetapi beberapa kali hingga tercapai tujuan yang diharapkan dalam pembelajaran bahasa Indonesia di kelas. Dalam setiap siklus terdiri dari empat kegiatan pokok, yaitu perencanaan (plan), pelaksanaan (act), pengamatan (observe), dan refleksi (reflect) (Hopkins dalam Arikunto 2006:74).

\section{Identifikasi awal}

1) Masalah dalam pembelajaran

2. Menganalisis Masalah

3) Merumuskan masalah. Merencanakan

1) Skenario pembelajaran .

2) Menyiapkan sarana dan prasarana pembelajaran.

3) Menyusun RPP

4) Menyiapkan Instrumen pengumpulam data Melakukan tindakan

1) Melakukan pelaksanaan tindakan penelitian Observasi

1) $\{$ Mengamati dan menginterprestas Merefleksi
1) Melakukan perbaikan dalam pembelajaran 


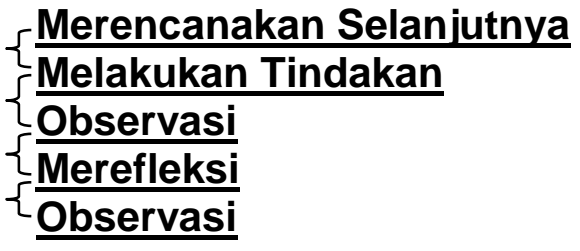

Dalam penelitian ini akan dianalisis dengan menggunakan analisis kualitatif dan kuantitatif. Analisis kualitatif akan digunakan untuk menganalisis data yang menunjukkan dinamika proses dengan memberikan pemaknaan secara kontekstual dan mendalam sesuai dengan permasalahan penelitian, yaitu data rentang kinerja guru, aktivitas belajar peserta didik, pola interaksi tentang penggunaan media gambar berseri dalam pembelajaran. Selama kegiatan pembelajaran berlangsung aktivitas siswa yang sesuai dengan indikator dicatat dalam lembar observasi. Setelah dilakukan pengamatan kemudian dihitung jumlah aktivitas yang dilakukan setiap siswa, selanjutnya data yang diperoleh dipersentasikan dengan rumus:

$$
\mathrm{A}=\frac{N a}{N} \times 100 \%
$$

Keterangan:

$\% A=$ persentase siswa yang aktif

$\mathrm{Na}$ = jumlah siswa yang aktif

$\mathrm{N}=$ jumlah siswa keseluruhan

Sumber : (Sugiarsih U, Skripsi 2006)

\section{PEMBAHASAN}

\section{Siklus I}

1) Rencana Pelaksanaan meliputi :

a. Membuat Rencana Pelaksaan Pembelajaran (RPP).

b. Menyiapkan media pembelajaran dan evaluasi.

c. Menyiapkan lembar instrumen penelitian.

2) Tahap Pelaksanaan dan Observasi

a. Aktivitas Siswa Siklus I

b. Hasil Aktivitas Siswa Siklus I

c. Hasil Aktifitas Guru Siklus I

3) Refleksi

Pada akhir siklus I diperoleh bahwa aktivitas dan hasil belajar siswa belum memenuhi kriteria ketuntasan yang telah ditetapkan. Hal ini disebabkan karena penggunaan media gambar berseri belum memenuhi kondisi yang diharapkan. Guru belum optimal dalam pengelolaan pembelajaran. Berdasarkan hasil pengamatan observer terdapat beberapa hal yang perlu diperhatikan dari keseluruhan yang diamati yaitu:

a) Guru belum maksimal dalam mengkondisikan kelas dan dalam menghubungkan materi dengan gambar yang dibagikan pada siswa.

b) Guru kurang memberikan waktu kepada siswa untuk memperhatikan gambar berseri.

c) Guru belum maksimal dalam menggunakan alat/media pembelajaran.

d) Guru kurang memotivasi dan memberikan pemahaman tentang menulis deskripsi.

e) Guru belum dapat menyimpulkan materi serta menutup kegiatan pembelajaran dengan baik.

Kekurangan dalam pengelolaan pembelajaran juga terjadi pada siswa, seperti:

a) Dalam kegiatan pembelajaran, masih ada siswa yang ribut dan tidak memperhatikan penjelasan guru.

b) Sebagian besar siswa belum memahami materi yang disampaikan guru sehingga 
sebagian siswa dalam keadaan kebingungan.

c) Siswa kurang aktif untuk bertanya kepada guru.

d) Siswa kurang aktif dalam menulis deskrisi

4) Temuan Siklus I

a. Pada proses pembelajaran siswa cenderung diam dan sebagian lagi siswa melakukan kegiatan yang tidak relevan, seperti mengobrol dan mengganggu temannya.

b. Guru belum menguasai kelas serta guru kurang bisa membimbing siswa dalam menulis deskripsi.

c. Hasil pembelajaran belum mencapai indikator dikarenakan siswa masih dalam keadaan kebingungan untuk menulis deskripsi. Akan tetapi pada siklus 1 belum terjadi proses belajar yang baik dalam diri siswa sehingga tujuan pembelajaran belum tercapai dan peningkatan proses belajar belum mencapai indikator yang diharapkan

\section{Siklus II}

1) Rencana Pelaksanaan meliputi :

a. Membuat Rencana Pelaksaan Pembelajaran (RPP).

b. Menyiapkan media pembelajaran dan evaluasi.

c. Menyiapkan lembar instrumen penelitian.

2) Tahap Pelaksanaan dan Observasi

a. Aktivitas Belajar Siswa

b. Hasil Belajar Siswa Siklus II

c. Hasil Aktivitas guru siklus II

3) Refleksi

Penggunaan media gambar berseri pada siklus II sudah lebih baik dari siklus I. Hasil belajar dan aktivitas siswa mengalami peningkatan walaupun belum memenuhi kriteri ketuntasan yang ditetapkan. Pada siklus II siswa mulai memahami gambar berseri dalam menulis deskripsi dan siswa mulai aktif dalam menulis deskripsi.

Berdasarkan observasi yang dilakukan oleh observer terdapat beberapa hal yang perlu diperhatikan dari keseluruhan yang diamati, yaitu:

a) Guru belum maksimal dalam mengkondisikan kelas dan dalam menghubungkan materi dengan gambar yang dibagikan pada siswa.

b) Guru belum maksimal dalam mengelola waktu pembelajaran dengan baik.

c) Guru belum maksimal dalam memotivasi siswa dalam kegiatan kelompok dan membimbing siswa dalam menulis deskripsi.

Kekurangan dalam pengelolaan pembelajaran juga terjadi pada siswa, seperti:

a) Dalam kegiatan belajar siswa kurang memperhatikan penjelasan guru.

b) Dalam kegiatan menulis deskrisi siswa masih kurang aktif dan tidak mau bertanya kepada guru atau teman jika tidak mengerti dengan gambar atau materi yang diajarkan.

c) Pelaksanaan siklus II masih perlu dilakukan banyak perbaikan.

4) Temuan Siklus II

a. Hal yang tidak releven seperti ngobrol dan mengganggu teman.

b. Guru sudah bisa memotivasi serta membimbing anak dalam menulis deskripsi, akan tetapi tidak bisa sepenuhnya memberi bimbingan dan perhatian pada semua siswa.

c. Hasil pembelajaran pada siklus II meningkat, akan tetapi masih belum maksimal, siswa masih mengalami kebingungan dan 
kurang mampu mengembangkan sebuah ide serta gagasan.

\section{Siklus III}

1) Rencana Pelaksanaan meliputi :

a. Membuat Rencana Pelaksaan Pembelajaran (RPP).

b. Menyiapkan pembelajaran dan evaluasi.

c. Menyiapkan lembar instrumen penelitian.

2) Tahap Pelaksanaan dan Observasi

a. Aktivitas Belajar Siswa

b. Hasil belajar siswa siklus III

c. Hasil Aktivitas guru siklus III

3) Refleksi

Penggunaan media gambar berseri dalam menulis deskripsi pada siklus III sudah lebih baik dan terjadi peningkatan ketuntasan belajar, serta hasil belajar siswa mengalami peningkatan dalam setiap siklus. Aktivitas siswa pun mengalami peningkatan karena siswa sudah memahami media gambar berseri dalam menulis deskripsi. Pada akhir siklus III ini dapat dikatakan bahwa aktivitas siswa meningkat diiringi dengan peningkatan hasil belajar siswa pula yang sesuai dengan kriteria ketuntasan minimal (KKM) yang telah ditentukan sekolah.

4) Temuan Siklus III

a. Anak sudah banyak bertanya dan terlihat hanya beberapa anak saja yang diam dan melakukan kegiatan yang tidak relevan

b. Aktivitas guru meningkat terlihat dari guru dapat mengkondisikan kelas serta memberikan bimbingan, motivasi dan perhatian kepada siswa.

c. Hasil belajar siswa banyak terjadi peningkatan.

\section{SIMPULAN}

Kesimpulan yang dapat diambil dari penelitian ini adalah:

1. Pembelajaran bahasa Indonesia menggunakan media gambar berseri dapat meningkatkan keterampilan menulis deskripsi pada siswa kelas IV SD Negeri 01 Daya Asri Kabupaten Tulang Bawang Barat.

2. Peningkatan rata-rata hasil belajar, aktivitas siswa serta aktivitas guru merupakan ketercapaian Indikator keberhasilan penelitian tindakan kelas.

3. Rata-rata hasil dari siklus I sampai dengan siklus III meningkat. Ratarata hasil belajar dari siklus I sebesar $65 \%$, siklus II sebesar $69 \%$ dan siklus III sebesar $73 \%$. Peningkatan dari siklus I ke siklus II sebesar $4 \%$, dan siklus II ke siklus III sebesar $4 \%$.

4. Rata-rata aktivitas siswa pada siklus I sebesar $51 \%$, siklus II sebesar $70 \%$ dan siklus III sebesar $81 \%$. Peningkatan siklus I ke siklus II sebesar $19 \%$ dan siklus II ke siklus III sebesar $11 \%$.

5. Aktivitas guru mengalami peningkatan dari siklus ke siklus. Rata-rata aktivitas guru siklus I sebesar $46,5 \%$, siklus II sebesar $55 \%$, sedangkan siklus III sebesar $61 \%$. Peningkatan dari siklus I ke siklus II sebesar $8,5 \%$ dan siklus II ke siklus III sebesar $6 \%$.

Berdasarkan kesimpulan diatas, penulis merekomendasikan diantaranya sebagai berikut:

1. Kepada siswa, untuk senantiasa membudayakan belajar dan 
menulis, guna memperkaya ilmu pengetahuan dan memperoleh hasil belajar yang lebih baik.

2. Kepada orang tua, untuk selalu membimbing dan memotivasi putraputrinya agar rajin belajar dan mendampingi belajar agar anak menjadi nyaman dan senang untuk belajar.

3. Kepada guru, hendaknya menerapkan cara menulis deskripsi dengan media gambar berseri untuk meningkatkan keterampilan menulis siswanya. Pemilihan gambar hendaknya di sesuaikan tema pembelajaran serta pilihan gambar yang atraktif agar siswa tidak jenuh dalam belajar menulis sehingga proses pembelajaran dapat meningkat.

4. Kepada Sekolah, agar melengkapi sarana dan prasarana seperti media dan buku-buku bacaan dalam proses pembelajaran sehingga hasil pembelajaran dapat meningkat.

5. Dinas Pendidikan, agar menyediakan sarana dan prasarana pendidikan untuk pelatihan guru dalam pembalajaran.

\section{DAFTAR PUSTAKA}

Angkowo, Robertus. Kosasih A. Depdiknas. (2006). Pelaksanaan (2007). Optimalisasi Media Pembelajaran. Jakarta: PT Grasindo.

Ahmad, Hamzah, dkk. (2000). Kamus Pintar Bahasa Indonesia. Surabaya: Fajar Mulyana

Arikunto, Suharsimi, dkk. (2006). Penelitian Tindakan Kelas. Jakarta: PT Bumi Aksara

Arikunto, Suharsimi, dkk. (2007). Dasar-Dasar Evaluasi Pendidikan. Jakarta: PT Bumi Aksara Kurikulum Tingkat Satuan Pendidikan Jakarta: Balai Pustaka.

Djamarah, Syaiful Bahri, dkk. (2006). Strategi Belajar-Mengajar. Jakarta: PT Rineka Cipta.

Hernawan, Asep Herry, dkk. (2008). Pengembangan Kurikulum dan Pembelajaran. Jakarta: Universitas Terbuka.

Mikarsa, Lestari, Hera, dkk. (2007). Pendidikan Anak di SD. Jakarta: Universitas Terbuka.

Arsyad, Azhar. (2002). Media Pembelajaran. Jakarta : PT Raja Grafindo Persada Karya Aksara.

Cahyani, Isah dan lyos. (2007). Pendidikan Bahasa Indonesia. Bandung: UPI Press.

Depdiknas. (2002). Pedoman Penilaian Hasil Belajar Sekolah Dasar. Jakarta: Balai Pustaka.

Muslich, Masnur. (2009). KTSP Pembelajaran Berbasis Kompetensi dan Kontekstual. Jakarta: Bumi Aksara.

Maryani, (2009). Meningkatkan Kemampuan Siswa Dalam Menulis Karangan Melalui Penggunaan Media Gambar Seri di Kelas V SDN Cibulan. Kab. Majalengka. Skripsi. Fakultas Keguruan dan IImu 
Pendidikan:

Universitas

Pendidikan Indonesia.

Nasution, S. (2006). Kurikulum dan Pengajaran. Bandung. PT Bumi Aksara.

Nenden, Sundoro, dkk, (2006). Membaca dan Menulis di $S D$ Teori dan Pengajaranya. Bandung: Upi Press.

Resmini, Novi dkk. (2006). Pembinaan dan Pengembangan Pembelajaran Bahasa dan Sastra Indonesia edisi 1. Jakarta: Direktorat Jenderal Pendidikan Tinggi.

Rofi'uddin, Ahmad dkk. (1999). Pendidikan Bahasa dan Sastra Indonesia di Kelas Tinggi. Jakarta: Direktorat Jenderal Pendidikan Tinggi.

Sadiman S. Arif, dkk, (2006). Media pendidikan. Jakarta: PT Raja Grafindo Persada.

Sagala, Syaiful, (2008). Konsep dan Makna Pembelajaran Untuk Membantu Memecahkan Problematika Belajar dan Mengajar. Bandung: Alfabeta.

Santoso, Puji, dkk. (2008). Materi dan Pembelajaran Bahasa Indonesia. PGSD 4405/3 SKS. Jakarta: Universitas Terbuka.

Sugiarsih, U. (2006) Meningkatkan Aktivitas dan Hasil Belajar

$\begin{array}{lr}\text { Matematika } & \text { Melalui } \\ \text { Pembelajaran } & \text { Kinestetik } \\ \text { Dengan Permainan. Skripsi. } & \text { Sakultas Keguruan dan Ilmu } \\ \text { Pendidikan: } & \text { Universitas } \\ \text { Lampung } & \end{array}$

Sulaiman. (1998). Media pendidikan. Jakarta: CV Rajawali.

Suparno, dkk. (2006). Materi Pokok Keterampilan Dasar Menulis. Jakarta: Universitas Terbuka.

Suwarjo. (2008). Pembelajaran Kooperatif Dalam Apresiasi Prosa Fiksi(Kajian Konsep: Teori dan Strategi Pengembangannya). Malang: Surya Pena Gemilang.

Tarigan, Henry Guntur (1994). Menulis Sebagai Suatu Keterampilan Berbahasa. Bandung: Angkasa.

Wardhani, IGAK. dkk. (2007). Penelitian Tindakan Kelas. Jakarta: Universitas Terbuka.

Winataputra, S. Udin. dkk. (2008). TeoriBelajar dan Pembelajaran. Jakarta: Universitas Terbuka.

Warsito. (2009). Penggunaan Media Gambar Berseri Untuk Meningkatkan Keterampilan Menulis Karangan Narasi Siswa Kelas SD.Http://Whasit.blogspot.com/2 009/05/contoh-karya-ilmiah.html 